\title{
Evaluation of Deep-Seated Soft Tissue Foreign Bodies According to Gender and Age Groups
}

\author{
Derin Yerleşimli Yumuşak Doku Yabanci Cisimlerinin \\ Cinsiyet ve Yaş Gruplarina Göre Değerlendirilmesi
}

Mustafa Ozer, Mehmet Turker, Veysel Basbug, Kayhan Kesik, Faik Turkmen, Burkay Kutluhan Kacira, Ismail Hakkı Korucu, Tahsin Sami Colak, Recep Memik,

Necmettin Erbakan University Meram Faculty of Medicine, Department of Orthopaedics \& Traumatology, Konya, Turkey

Geliş Tarihi/Received: 24 September 2018 Kabul Tarihi/Accepted: 2 December 2018

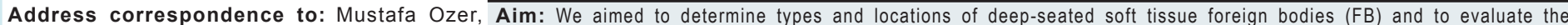
Necmettin Erbakan University Meram Faculty differences between gender and age groups.

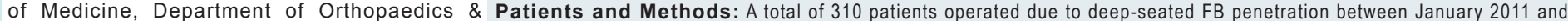
Traumatology, Konya, Turkey

e-mail: mozer208@yahoo.com

\section{ORCID}

Mustafa Ozer

https://orcid.org/0000-0002-4199-836X

Anahtar Kelimeler: Yabancı cisim, derin yerleşimli, el, ayak, iğne, metal parçası

\section{Abstract}

\begin{abstract}
Öz
Amaç: Çalışmadaki amacımız, derin yerleşimli yumuşak doku yabancı cisimlerinin tipinin ve yerleşim yerlerinin belirlenerek, cinsiyet ve yaş grupları arasındaki farklılıkların değerlendirilmesidir.

Hastalar ve Yöntem: Ocak 2011 ile Ocak 2018 yılları arasında derin yerleşimli yabancı cisim penetrasyonu nedeniyle cerrahi uygulanan 310 hasta çalışmaya dahil edildi. Hastalar 18 yaş altı, 18-45 yaş arası ve 45 yaş üzeri olmak üzere 3 gruba ayrıldı. Yabancı cisimler 5 gruba ayrıldı. Yabancı cisim yerleşim yeri olarak üst ekstremite 5 bölgeye, alt ekstremite ise 6 bölgeye ayrıldı. Yabancı cisim tipi ve yerleşim yeri, yaş gupları ve cinsiyete göre karşılaştırılarak analiz edildi.

Bulgular: Erkeklerde en sık karşılaşılan yabancı cisim $\% 48,4$ metal parçasıyken, kadınlarda $\% 77,3$ iğneydi $(P<, 0001)$ 18 yaş altı erkeklerde en sık karşılaşılan yabancı cisim \%67,4 iğneyken, kadınlarda \%94,2 iğneydi ( $P=, 12)$. 18-45 yaş aras erkeklerde en sık karşılaşılan yabancı cisim \%54,7 metal parçasıyken, kadınlarda \%71,4 iğneydi ( $P=, 0007)$. 45 yaş üzeri erkeklerde en sık karşılaşılan yabancı cisim \%61,3 metal parçasıyken, kadınlarda \%70 iğneydi $(P=, 0023)$. Erkeklerde en sık yabancı cisim yerleşim yeri \%35,2 elken, kadınlarda \%61 ayaktı ( $\mathrm{P}<, 0001) .18$ yaş altı erkeklerde en sık yabancı cisim yerleşim yeri $\% 65,1$ ayakken, kadınlarda $\% 62,9$ ayaktı $(P=, 04) .18-45$ yaş arası erkeklerde en sık yabancı cisim yerleşim yeri $\% 38,9$ elken, kadınlarda $\% 60,3$ ayaktı $(P<, 0001)$. 45 yaş üzeri erkeklerde en sık yabancı cisim yerleşim yeri \%65,5 elken, kadınlarda \%60 ayaktı $(\mathrm{P}<, 0001)$

Sonuç: Çalışmamız derin yerleşimli yabancı cisimlerin tipi ve bulunduğu anatomik bölgenin yaş grupları ve cinsiyete göre değerlendirildiği literatürdeki ilk çalışmadır. Kadınlarda tüm yaş gruplarında ve 18 yaş altı erkeklerde; en sık tesbit edilen yabancı cisim yerleşim yeri ve tipi sırasıyla ayak ve iğne olarak bulundu. Bu sonuç, evde sıklıkla dikiş için kullanılan iğnenin bireylerin dikkatsizliği veya inmali sonucu yere düşürülmesi ve bu grupların evde daha fazla vakit geçirmesi ile ilişkili olabilir. 18 yas üstü erkeklerde ise en sık tesbit edilen yabancı cisim yerleşim yeri ve tipi sırasıyla el ve metal parçası olarak bulundu. Bu sonuç da, penetran el yaralanmaları için risk altında olan ağır iş yapan işçi sınıfının çoğunlukla 18 yaş üstü erkek cinsiyette olması ile ilişkili olabilir.
\end{abstract} \begin{abstract}
January 2018 were included in the study. Patients were divided into three groups as under 18 years, 18-45 years, and over 45 years. FB were divided into five groups. Locations of the FB were divided into five region in the upper extremities and into six region in the lower extremities. FB type and location were analyzed according to the gender and age groups.

Results: The most common FB was metal piece in men by $48.4 \%$, and needle in women by $77.3 \%(P<.0001)$. Needle was the most common FB by $67.4 \%$ in men and $94.2 \%$ in women who aged under 18 years $(P=.12)$, whereas the most common FB was metal piece by $54.7 \%$ in men and needle by $71.4 \%$ in women in the aged $18-45$ years age group $(P=.0007)$ and metal piece by $61.3 \%$ in men and needle by $70.0 \%$ in women in the over 45 years age group $(P=.0023)$. The most common location of $\mathrm{FB}$ was hand in men by $35.2 \%$ and foot in women by $61 \%(\mathrm{P}<.0001)$. The most common location of $\mathrm{FB}$ was foot by $65.1 \%$ in men, and foot by $62.9 \%$ in women who aged under 18 years $(P=.04)$, whereas the most common location of $F B$ was hand by $38.9 \%$ in men aged $18-45$ years and foot by $60.3 \%$ in women in the same age group $(P=<.0001)$. The most common location of FB was hand by $65.5 \%$ in men and foot by $60 \%$ in women who aged over 45 years $(P<.0001)$.

Conclusion: Our study is the first in the literature to evaluate the type and location of the deep-seated FB according to the gender and age groups. The most common location and type of FB were found as foot and needle in women of all age groups and in men under 18 years. This result may be related to the reason that needles, which is used for sewing, are often dropped to the floor due to inattention or neglect of persons, and these persons spend more time at home. Whereas, the most common location and type of FB were hand and metal piece in men over 18 years, respectively. This result may be associated with the labor class doing heavy work which is under risk for hand injury and consists of men over 18 years.
\end{abstract}

Key words: Foreign body, deep-seated, hand, foot, needle, metal piece

\section{INTRODUCTION}

One of the conditions requiring orthopedic intervention in emergency is the presentation of soft tissue foreign bodies (FB). Although FB penetration to the extremities is considered as simple injuries, its treatment is not easy because of the difficulties in finding the location of the FB (1). While superficiallyseated FB can be removed under local anesthesia in the intervention room in emergency department, deep-seated ones can be removed in the operating room setting using fluoroscopy or ultrasound (US). While radiopaque FB can be easily detected in
Cite this article as: Ozer M, Turker M, Basbug V, Kesik K, Turkmen F, Kacira BK, Korucu IH, Colak TS, Memik R. Evaluation of Deep-Seated Soft Tissue Foreign Bodies Accord-ing to Gender and Age Groups. Selcuk Med J 2019;35(1): 24-30
Disclosure: None of the authors has a financial interest in any of the products, devices, or drugs mentioned in this article. The research was not sponsored by an outside organization. All authors have agreed to allow full access to the primary data and to allow the journal to review the data if requested. 
radiographic imaging, US or magnetic resonance imaging (MRI) methods can be used in suspected cases of radiolucent FB since they can not be detected with radiography (2).

Anderson et al. (3) reported that the diagnosis was missed out in $38 \%$ of patients with soft tissue FB and underlined the importance of FB properties in establishing the diagnosis. All metal FB can be diagnosed as they are radiopaque, however, the diagnosis can be set by $96 \%$ in glass and $15 \%$ in wood. Given that the pain, soft tissue infection and iatrogenic injuries may occur in delayed diagnosis, knowing the properties of FB according to the gender and age groups may be helpful for early diagnosis.

In this study, we aimed to determine type and location of deep-seated FB that were intervened in the operating room conditions, and to evaluate the differences between gender and age groups.

\section{PATIENTS AND METHODS}

A total of 310 patients who underwent surgical intervention under operating room conditions due to deep-seated FB penetration in our clinic between January 2011 and January 2018 were retrospectively evaluated and included in this study. Demographic information and diagnosis of the patients were obtained from the hospital medical records. Of all patients, 128 were female $(41.3 \%)$, and 182 were male $(58.7 \%)$. The mean age was $30.69 \pm 16.66$ (range, 3 to 79 ) years.

Patients were divided into three group by age groups as under 18 years (Group 1), 18-45 years (Group 2), and over 45 years (Group 3). FB were divided into five groups as needle, glass, metal piece, wood, and plastic. Locations of the FB were divided into five region in the upper extremities (arm, elbow, forearm, wrist, hand), and into six region in the lower

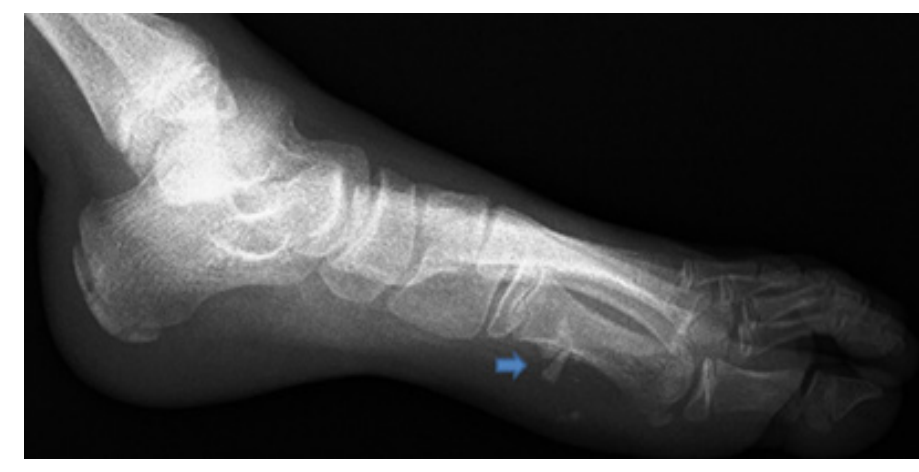

Figure 1. Image of a glass in the sole of foot on right foot lateral radiograph (blue arrow)

extremities (hip, thigh, around knee, crusis, ankle, foot). FB type and location were analyzed according to gender and age groups. Demographic data of the groups are shown in Table 1.

Patients were preoperatively questioned for tetanus prophylaxis and administered prophylaxis if deemed necessary. After administration of prophylaxis (first generation cephalosporin), anesthesia was induced considering age of the patients and location of the FB (general anesthesia, local anesthesia, spinal anesthesia, peripheral nerve block, or intravenous regional anesthesia), and tourniquet was applied for the FB in the distal of knee or elbow. Radiopaque FB were visualized using fluoroscopy and radiolucent FB using US, and FB location, size, and number of fragments were determined (Figures 1-3). Considering entry area of the FB, surgical area is established and prepared. Then, the FB is removed by entering through an incision which is large enough to remove the FB, but small as much as possible. Following abundant irrigation and ensuring that the entire FB

Table 1. Demographic data of all patients based on different age groups. Note: Data are presented as mean \pm standard deviation (minimum-maximum).

\begin{tabular}{lllll}
\hline Characteristics & All Patients (\%) & Group 1 (\%) & Group 2 (\%) & Group 3 (\%) \\
\hline $\begin{array}{l}\text { Patients (n) } \\
\text { Age }\end{array}$ & $310(100)$ & $78(25.2)$ & $171(55.2)$ & $61(19.6)$ \\
$\begin{array}{l}\text { Sex } \\
\quad \text { Male }\end{array}$ & $30.69 \pm 16.66(3-79)$ & $12.11 \pm 3.44(3-14)$ & $29.41 \pm 8.39(18-45)$ & $57.38 \pm 8.17(46-79)$ \\
$\quad$ Female & $182(58.7)$ & $43(55.1)$ & & \\
$\begin{array}{l}\text { Side } \\
\quad \text { Right }\end{array}$ & $128(41.3)$ & $35(44.9)$ & $63(36.9)$ & $31(50.8)$ \\
$\quad \begin{array}{l}\text { Left } \\
\text { Extremity }\end{array}$ & $162(52.2)$ & $38(48.7)$ & $91(53.2)$ & $30(49.2)$ \\
$\quad$ Upper & $148(47.8)$ & $40(51.3)$ & $80(46.8)$ & $33(54.1)$ \\
$\quad$ Lower & $100(32.2)$ & $4(5.1)$ & $65(38)$ & $28(45.9)$ \\
\hline
\end{tabular}




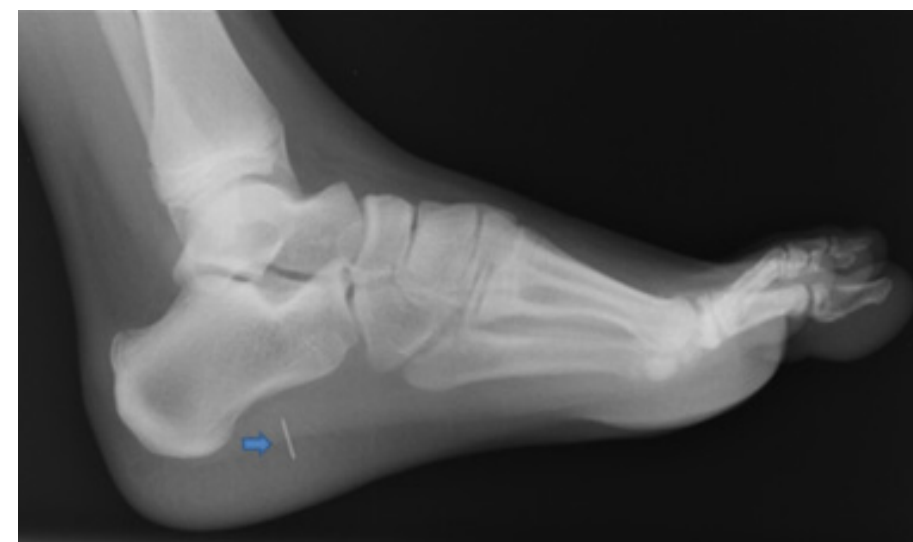

Figure 2. Image of a needle in the sole of foot on right foot lateral radiograph (blue arrow)

was removed, the skin was closed.

\section{Statistical analysis}

Statistical analysis was performed using the SPSS (Statistical Package for Social Sciences) software (Version 21.0; SPSS Inc, Chicago, IL). Frequency, mean, and standard deviation values were calculated by descriptive statistical methods. Numeric variables were assessed using the Mann-Whitney $U$ test. Dichotomous variables were assessed by Crosstabs and Pearson's Chi-Square test or Fisher's Exact test. For all comparisons, $\mathrm{P}$ values $<0.05$ (2-tailed) were considered statistically significant.

\section{RESULTS}

Of 310 patients included in the study, $78(25.2 \%)$ were under 18 years, 171 (55.2\%) were 18-45 years, and 61 (19.6\%) were over 45 years. Whereas FB were in the lower extremities in 210 (67.8\%) patients, they were in the upper extremities in $100(32.2 \%)$ patients. Lower extremity localized FB were found by $94.9 \%$ in group 1, 62\% in group 2 and $49.2 \%$ in group 3 (Table 1).

The most common FB in all patients was needle by $51.9 \%$ followed by metal piece by $30.4 \%$. The most common FB in group 1 was needle by $79.4 \%$ followed

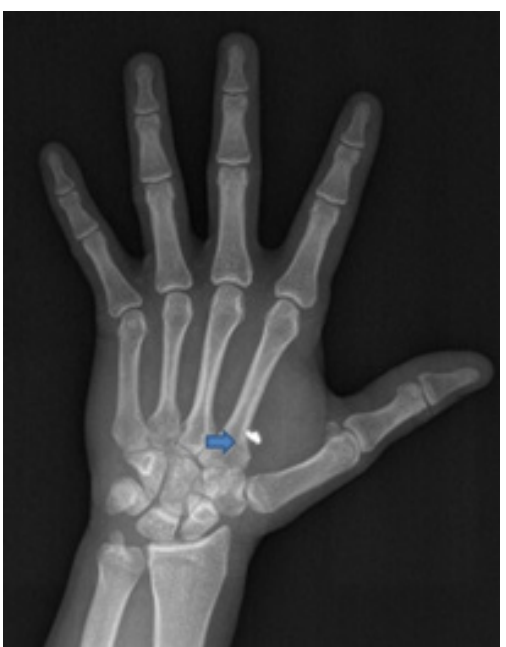

Figure 3. Image of a metal piece in the right hand anteriorposterior radiograph (blue arrow)

by metal piece by $10.3 \%$. The most common FB in group 2 was needle by $42.7 \%$ followed by metal piece by $38.7 \%$. The most common FB in group 3 was needle by $42.6 \%$ followed by metal piece by $32.8 \%$. $(\mathrm{P}<.0001)$ (Table 2).

The most common FB in all men was metal piece by $48.4 \%$ followed by needle by $34.1 \%$. The most common FB in women was needle by $77.3 \%$ followed by glass and plastic by $5.5 \%(\mathrm{P}<.0001)$. The most common FB in men under 18 years was needle by $67.4 \%$ followed by metal piece by $16.2 \%$. The most common FB in women under 18 years was needle by $94.2 \%$ followed by glass and metal piece by $2.9 \%$ $(P=.12)$. The most common FB encountered in men aged $18-45$ years was metal piece by $54.7 \%$ followed by needle by $26 \%$. The most common FB encountered in women aged $18-45$ years was needle by $71.4 \%$ followed by wood by $9.5 \% \quad(P=.0007)$. The most common FB in men over 45 years was metal piece by $61.3 \%$ followed by needle by $16.1 \%$. The most common FB in women over 45 years was needle by $70 \%$ followed by plastic by $13.4 \%(P=.0023)$ (Table 3).

The most common location of FB in all patient was

Table 2. Distribution of the foreign body types by all patients and age groups. Note:* $P<0.05$

\begin{tabular}{llllll}
\hline Foreign Body & All Patients (\%) & Group 1 (\%) & Group 2 (\%) & Group 3 (\%) & P values \\
\hline Needle & $161(51,9)$ & $62(79.4)$ & $73(42.7)$ & $26(42.6)$ & $<.0001^{*}$ \\
Glass & $21(6.8)$ & $4(5.1)$ & $13(7.6)$ & $4(6.6)$ & \\
Metal piece & $94(30.4)$ & $8(10.3)$ & $66(38.7)$ & $20(32.8)$ \\
Wood & $19(6.1)$ & $2(2.6)$ & $10(5.8)$ & $7(11.4)$ \\
Plastic & $15(4.8)$ & $2(2.6)$ & $9(5.2)$ & $4(6.6)$ & \\
\hline
\end{tabular}


Table 3. Distribution of the foreign body types according to gender by all patients and age groups. Note:* $P<0.05$

\begin{tabular}{|c|c|c|c|c|c|c|c|c|}
\hline \multirow[t]{2}{*}{ Foreign Body } & \multicolumn{2}{|c|}{ All Patients (\%) } & \multicolumn{2}{|c|}{ Group 1 (\%) } & \multicolumn{2}{|c|}{ Group 2 (\%) } & \multicolumn{2}{|c|}{ Group 3 (\%) } \\
\hline & M & $\mathbf{F}$ & M & $\mathrm{F}$ & $\mathbf{M}$ & $\mathrm{F}$ & & $\mathbf{F}$ \\
\hline Needle & $62(34.1)$ & $99(77.3)$ & $29(67.4)$ & $33(94.2)$ & $28(26)$ & $45(71,4)$ & $5(16.1)$ & $21(70)$ \\
\hline Glass & $14(7.7)$ & $7(5.5)$ & $3(7)$ & $1(2.9)$ & $8(7.4)$ & $5(8)$ & $3(9.6)$ & $1(3.3)$ \\
\hline Metal piece & $88(48.4)$ & $6(4.7)$ & $7(16.2)$ & $1(2.9)$ & $62(54.7)$ & $4(6.3)$ & $19(61.3)$ & $1(3.3)$ \\
\hline Wood & $10(5.5)$ & $9(7)$ & $2(4.7)$ & - & $4(3.7)$ & $6(9.5)$ & $4(13)$ & $3(10)$ \\
\hline Plastic & $8(4.3)$ & $7(5.5)$ & $2(4.7)$ & - & $6(5.6)$ & $3(4.8)$ & - & $4(13.4)$ \\
\hline$P$ values & \multicolumn{2}{|c|}{$<.0001^{*}$} & \multicolumn{2}{|c|}{.12} & \multicolumn{2}{|c|}{$.0007^{*}$} & \multicolumn{2}{|c|}{$.0023^{*}$} \\
\hline
\end{tabular}

Table 4. Distribution of the foreign body locations by all patients and age groups. Note: $P<0.05$

\begin{tabular}{|c|c|c|c|c|c|}
\hline Location & All Patients (\%) & Group $1(\%)$ & Group $2(\%)$ & Group $3(\%)$ & P values \\
\hline Arm & $3(1)$ & - & $2(1.1)$ & $1(1.6)$ & \\
\hline Elbow & $8(2.6)$ & - & $6(3.5)$ & $2(3.3)$ & \\
\hline Forearm & $8(2.6)$ & - & $7(4.2)$ & $1(1.6)$ & \\
\hline Wrist & $3(1)$ & $1(1.3)$ & $2(1.1)$ & & \\
\hline Hand & $78(25.1)$ & $3(3.9)$ & $48(28.2)$ & $27(44.3)$ & \\
\hline Hip & $5(1.6)$ & $1(1.3)$ & $3(1.7)$ & $1(1.6)$ & $<.0001^{*}$ \\
\hline Thigh & $15(4.8)$ & $3(3.9)$ & $10(5.8)$ & $2(3.3)$ & \\
\hline Around knee & $31(10)$ & $15(19)$ & $15(8.8)$ & $1(1.6)$ & \\
\hline Cruris & $15(4.8)$ & $3(3.9)$ & $10(5.8)$ & $2(3.3)$ & \\
\hline Ankle & $6(2)$ & $2(2.6)$ & $3(1.7)$ & $1(1.6)$ & \\
\hline Foot & $138(44.5)$ & $50(64.1)$ & $65(38.1)$ & $23(37.8)$ & \\
\hline
\end{tabular}

foot by $44.5 \%$ followed by hand by $25.1 \%$. The most common location of FB in group 1 was foot by $64.1 \%$ followed by around knee by $19 \%$. The most common location of FB in group 2 was foot by $38.1 \%$ followed by hand by $28.2 \%$. The most common location of FB in group 3 was hand by $44.3 \%$ followed by foot by $37.8 \%(\mathrm{P}<.0001)$ (Table 4).

The most common location of FB in all men was hand by $35.2 \%$ followed by foot by $33 \%$. The most common location of FB in women was foot by $61 \%$ followed by around knee by $11.8 \%(\mathrm{P}<.0001)$. The most common location of FB in men under 18 years was foot by $65.1 \%$ followed by around knee by $18.6 \%$. The most common location of FB in women under 18 years was foot by $62.9 \%$ followed by around knee by $20 \%(P=.04)$. The most common location of FB

Table 5. Distribution of the foreign body locations according to gender by all patients and age groups. Note: ${ }^{*}<0.05$

\begin{tabular}{|c|c|c|c|c|c|c|c|c|}
\hline \multirow[t]{2}{*}{ Location } & \multicolumn{2}{|c|}{ All Patients (\%) } & \multicolumn{2}{|c|}{ Group $1(\%)$} & \multicolumn{2}{|c|}{ Group 2 (\%) } & \multicolumn{2}{|c|}{ Group 3 (\%) } \\
\hline & M & $\mathbf{F}$ & $\mathbf{M}$ & $F$ & M & $\mathrm{F}$ & M & $\mathbf{F}$ \\
\hline Arm & $3(1.6)$ & - & - & - & $2(1.9)$ & - & $1(3.3)$ & - \\
\hline Elbow & $6(3.3)$ & $2(1.5)$ & - & - & $4(3.7)$ & $2(3.2)$ & $2(6.4)$ & - \\
\hline Forearm & $5(2.8)$ & $3(2.3)$ & - & - & $5(4.6)$ & $2(3.2)$ & - & $1(3.3)$ \\
\hline Wrist & $2(1.1)$ & $1(0.8)$ & $1(2.3)$ & - & $1(0.9)$ & $1(1.6)$ & - & - \\
\hline Hand & $64(35.2)$ & $14(11)$ & $2(4.7)$ & $1(2.8)$ & $42(38.9)$ & $6(9.5)$ & $20(64.5)$ & $7(23.3)$ \\
\hline Hip & $1(0.6)$ & $4(3.1)$ & - & $1(2.8)$ & $1(0.9)$ & $2(3.2)$ & - & $1(3.3)$ \\
\hline Thigh & $11(6)$ & $4(3.1)$ & $2(4.7)$ & $1(2.8)$ & $7(6.5)$ & $3(4.7)$ & $2(6.4)$ & - \\
\hline Around knee & $16(8.8)$ & $15(11.8)$ & $8(18.6)$ & $7(20)$ & $8(7.4)$ & 7 (11.1) & - & $1(3.3)$ \\
\hline Cruris & $11(6)$ & $4(3.1)$ & $1(2.3)$ & $2(5.7)$ & $9(8.3)$ & $1(1.6)$ & $1(3.3)$ & $1(3.3)$ \\
\hline Ankle & $3(1.6)$ & $3(2.3)$ & $1(2.3)$ & $1(2.8)$ & $2(1.9)$ & $1(1.6)$ & - & - \\
\hline Foot & $60(33)$ & $78(61)$ & $28(65.1)$ & $22(62.9)$ & $27(25)$ & $38(60.3)$ & $5(16.1)$ & $18(60)$ \\
\hline$P$ values & & $.0001^{*}$ & & $4^{*}$ & & $.0001^{*}$ & & $0001^{*}$ \\
\hline
\end{tabular}


Table 6. Distribution of the foreign body locations according to gender by all patients and age groups. Note: $P<0.05$

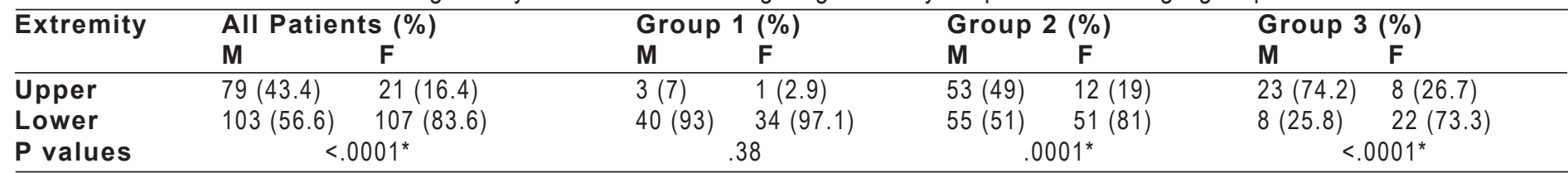

encountered in men aged $18-45$ years was hand by $38.9 \%$ followed by foot by $25 \%$. The most common location of FB encountered in women aged 18-45 years was foot by $60.3 \%$ followed by around knee by $11.1 \%(\mathrm{P}<.0001)$. The most common location of FB in men over 45 years was hand by $65.5 \%$ followed by foot by $16.1 \%$. The most common location of FB in women over 45 years was foot by $60 \%$ followed by hand by $23.3 \%(P<.0001)$ (Table 5$)$.

Location of $\mathrm{FB}$ was found as the lower extremity in $56.6 \%$ of all men, and $83.6 \%$ in all women $(P<.0001)$. Location of FB was found as the lower extremity in $93 \%$ of men under 18 years, and $97.1 \%$ of women under 18 years $(P=.38)$. Location of $F B$ was found as the lower extremity in $51 \%$ of men aged $18-45$ years, and $81 \%$ of women in the same age group ( $P=.0001)$. Location of FB was found as the upper extremity in $74.2 \%$ of men over 45 years, and as lower extremity in $73.3 \%$ of women over 45 years $(P<.0001)$ (Table $6)$.

\section{DISCUSSION}

To our knowledge, it is the first in the literature to evaluate type and location of deep-seated FB according to gender and age groups. First, looking to the extremity locations of the deep-seated FB, we found that $94.9 \%$ of the FB were localized in the lower extremity in under 18 years group. This rate was $62 \%$ and $49.2 \%$ in $18-45$ years, and over 45 years groups, respectively. Looking to the extremity locations of the FB by gender, $74.2 \%$ of the FB were upper extremity localized in men, and $73.3 \%$ were lower extremity localized in women in over 45 years group. The incidence of localization in upper extremity for deepseated FB penetration increased by age, and we think this result may be related to labor class doing heavy works which is at risk for penetrating hand injuries (4) and mainly consists of men aged over 18 years old. However, there is a need for further studies to evaluate type of injury in addition to location of the FB. $75.6 \%$ of the FB were localized in distal of the extremities in under 18 years group, while this rate was $79.1 \%$ and $88.6 \%$ in $18-45$ years and over 45 years groups. Ceylan et al. (5) reported the rate of FB localized in distal of the extremities as $80 \%$.

In our study, the most common location of the FB in all patients was foot by $44.5 \%$, followed by hand by $25.1 \%$. Kurtulmuş et al. (1) reported the most common location of FB as foot by $54.7 \%$ followed by hand by $25.4 \%$. Similarly, Polat et al. (2) reported the most common location as foot by $53.3 \%$, followed by hand by $26.6 \%$. Other studies also reported similar results $(4,6)$. However, the distribution varies when the assessment was made according to the gender and age groups. The most common location of $F B$ was foot by higher than $60 \%$ in women of all age groups. Whereas the most common location of FB was foot by $65.1 \%$ in men under 18 years, hand by $38.9 \%$ in men aged $18-45$ years, and hand by $65.5 \%$ in men over 45 years. Unlike male patients under 18 years and female patients in all age groups who showed similar features in terms of the location of FB, in men over 18 years, higher incidence of FB localized in hands may be resulted from that, as mentioned above that the labor class in under heavy work which puts this group at risk for hand injury.

The most frequently reported FB in patients who underwent surgery include needle, metal piece, glass, and wood (1,5,7-10). In our study, the most common FB type in all patients was found as needle by $51.9 \%$, followed by metal piece by $30.4 \%$. Kurtuluş et al. (1) reported the most common type of FB as needle by $73.2 \%$, followed by metal piece by $11.2 \%$. We found the most common type of FB as needle by higher than $70 \%$ in women of all age groups, whereas the most common type of FB was found as needle by $67.4 \%$ in men under 18 years, metal piece by $54.7 \%$ in men aged $18-45$ years, and again metal piece by 61.3 in men over 45 years. Unlike the other patients, significantly higher incidence of metal piece as the type of FB in men over 18 years may be attributed to this age group is compatible with gender and age of labor class working in industrial works. The most common location and type of FB were found as foot and needle in women of all age groups and men under 18 years. This result may be related to the 
unique feature of needles which are used for sewing and often dropped to the floor due to inattention or neglect of persons, and these persons spend more time at home.

Knowing type of the FB, thus knowing whether it is radiopaque or radiolucent is of paramount importance during diagnosis and surgery. Since metallic FB, such as needle and metal piece are radiopaque, they can be easily seen with direct radiography or fluoroscopy. Especially deep-seated glass FB $>2 \mathrm{~mm}$ can be seen by $99 \%$ with direct radiography, while those $<2 \mathrm{~mm}$ are seen by 61 to $83 \%$ with radiography (11). On the other hand, US and MRI can be used to visualize radiolucent FB such as wood and plastic (12-14). Since particularly radiolucent small pieces may not be visualized, more care should be taken in these patients to avoid residual fragments. As wood FB are organic, they create an environment over time for growth of microorganisms (15). Therefore, the risk of infection is high especially in the presence of residual wood pieces. Possible complications associated with residual pieces include; infection, persistent pain, swelling, migration, osteomyelitis, delayed healing, and pseudotumor (10,16-22). Previous studies have reported higher risk of complication with glass and wood FB (23-25). Patients should be informed about the possibility of residual FB especially after removal of radiolucent $F B$, and patients with complaints during the follow up should be evaluated for residual FB.

There are several limitations of the current study. First, although the data were collected prospectively, the study was designed retrospectively. Another limitation is that since our study is a single center study, our patients may not reflect general population. It is important for studies to be conducted in future to include injury mechanisms and patients' professions.

In conclusion; our study is the first in the literature to evaluate type and location of the FB according to gender and age groups. The most common location and type of FB were found as foot and needle, respectively in women of all age groups and men under 18 years. This result may be related with that a needle which is used for sewing is often dropped to the floor due to inattention or neglect of persons, and these persons spend more time at home. Whereas the most common location and type of the FB were found as hand and metal piece, respectively in men over 18 years. This result may be associated with that labor class doing heavy work that is under a risk for hand injury mostly consists of men over 18 years.
Conflict of interest: Authors declare that there is no conflict of interest between the authors of the article.

Financial conflict of interest: Authors declare that they did not receive any financial support in this study.

Address correspondence to: Mustafa Ozer, Yunus Emre Mah. Necmettin Erbakan University, Meram Faculty of Medicine, Department of Orthopaedics \& Traumatology, Konya, Turkey, 42080

Telephone: +90332 2236399, +905555180042

e-mail:mozer208@yahoo.com

\section{REFERENCES}

1. Kurtulmus T, Saglam N, Saka G, et al. Tips and tricks in the diagnostic workup and the removal of foreign bodies in extremities. Acta Orthop Traumatol Turc 2013;47(6):387-92.

2. Polat B, Atıcı Y, Gürpınar T, et al. Diagnosis and treatment of retained wooden foreign bodies in the extremities using ultrasound. Acta Ortop Bras 2018;26(3):198-200.

3. Anderson M, Newmeyer WL, Kilgore ES. Diagnosis and treatment of retained foreign bodies in the hand. Am J Surg 1982;144(1):63-7.

4. Salati SA, Rather A. Missed foreign bodies in the hand: An experience from a center in Kashmir. Libyan J Med 2010;12:5.

5. Ceylan MF, Guner S, Ediz L, et al. Removal of metallic foreign bodies embedded in soft tissues by stereotaxic approach. Afr Health Sci 2014;14(1):64-71.

6. Nagendran T. Management of foreign bodies in the emergency department. Hospital Physician 1999:9;27-40.

7. Peterson JJ, Bancroft LW, Kransdorf MJ. Wooden foreign bodies: Imaging appearance. Am J Roentgenol 2002;178:557-62.

8. Ozsarac M, Demircan A, Sener S. Glass foreign body in soft tissue: Possibility of high morbidity due to delayed migration. J Emerg Med 2009;20:30-4.

9. Hunter TB, Taljanovic MS. Foreign bodies. Radiographics 2003;23:731-57.

10. Sidharthan S, Mbako AN. Pitfalls in diagnosis and problems in extraction of retained wooden foreign bodies in the foot. Foot Ankle Surg 2010;16:e18-20.

11. Courter BJ. Radiographic screening for glass foreign bodieswhat does a "negative" foreign body series really mean? Ann Emerg Med 1990;19:997-1000.

12. Coombs CJ, Mutimer KL, Slattery PG, et al. Hide and seek: Pre-operative ultrasonic localization of non radioopaque foreign bodies. Aust N Z J Surg 1990;60:989-91.

13. Shiels WE, Babcock DS, Wilson JL, et al. Localization and guided removal of soft-tissue foreign bodies with sonography. AJR Am J Roenigetiol 1990;155:1277-81.

14. Monu JU, McManus CM, Ward WG, et al. Soft-tissue masses caused by long-standing foreign bodies in the extremities: MR imaging findings. Am J Roentgenol 1995;165:395-7.

15. Ginsberg LE, Williams DW, Mathews VP. CT in penetrating craniocervical injury by wooden foreign bodies: Reminder of a pitfall. Am J Neuroradiol 1993;14:892-5.

16. Rubin G, Chezar A, Raz R, et al. Nail puncture wound through a rubber-soled shoe: A retrospective study of 96 adult patients. J Foot Ankle Surg 2010;49:421-5.

17. Vargas B, Wildhaber B, La Scala G. Late migration of a foreign body in the foot 5 years after initial trauma. Pediatr 
Emerg Care 2011;27:535-6.

18. Gregory B, Anvesh R, Moroz PJ. Foreign body migration along a tendon sheath in the lower extremity: A case report and literature review. J Bone Joint Surg Am 2011;20;93:e38.

19. Bu J, Overgaard KA, Viegas SF. Distal migration of a foreign body (sago palm thorn fragment) within the long-finger flexor tendon sheath. Am J Orthop (Belle Mead NJ) 2008;37:208-9.

20. Dürr HR, Stäbler $A$, Müller $P E$, et al. Thorn-induced pseudotumor of the metatarsal. A case report. J Bone Joint Surg Am 2001;83:580-5.

21. Wegener B, Ficklscherer A, Muller PE, et al. Toothpick injury simulating a pigmented villonodular synovialitis. J Pediatr Surg 2009;44:e29-32.
22. Pushpasekaran N, Muthulingam M, Marimuthu $C$, et al. Unusual presentation of foreign body granuloma of the foot after sharp injury mimicking a malignant lesion: A case report. J Foot Ankle Surg 2017;56(6):1276-8.

23. Potini VC, Francisco R, Shamian B, et al. Sequelae of foreign bodies in the wrist and hand. Hand 2013;8:77-81.

24. Graham DD. Ultrasound in the emergency department: Detection of wooden foreign bodies in the soft tissues. J Emerg Med 2002;22(1):75-9.

25. Halaas GW. Management of foreign bodies in the skin. Am Fam Physician 2007;76(5):683-8. 